\title{
Nature of AU Mission in Somalia (AMISOM) in Relation to Peace Building Strategies in Somalia
}

\author{
William Oluoch Ligawa, Pontian Godfrey Okoth, Frank Khachina Matanga \\ Department of Peace and Conflict Studies, Masinde Muliro University of Science and Technology, Kakamega, Kenya \\ Email: ligwawilson@gmail.com
}

How to cite this paper: Ligawa, W.O., Okoth, P.G. and Matanga, F.K. (2017) Nature of AU Mission in Somalia (AMISOM) in Relation to Peace Building Strategies in Somalia. Open Access Library Journal, 4: e3248. https://doi.org/10.4236/oalib.1103248

Received: November 21, 2016

Accepted: October 16, 2017

Published: October 19, 2017

Copyright (C) 2017 by authors and Open Access Library Inc.

This work is licensed under the Creative Commons Attribution International License (CC BY 4.0).

http://creativecommons.org/licenses/by/4.0/

\section{(c) () Open Access}

\begin{abstract}
With the collapse of the central government, Somalia was engulfed into a predatory violence from the warlords. It saw deaths and acute humanitarian crisis amidst the vulnerable population. In nearly over two decades, peace still remains a dream in the failed state. The efforts to restore peace and stabilize the nation have proved to be futile. The weak Federal Government of Somalia struggles to run the state from the comforts of Mogadishu since most parts are still under the control of Al shabaab and other clan militias. Even in the capital mortar shells fired by the militants can be heard regularly. Suicide bombers pose a major threat to Mogadishu and other high value targets within the town. The researchers targeted AMISOM personnel and locals. The primary data was collected through interviews and questionnaires. Secondary data was gathered and reviewed from journals, books, magazines, newspapers and published proceedings that corroborated the primary data. The study found out that the nature of AMISOM needs to be realigned to facilitate the peace building efforts. The study recommends that operations should major on winning the hearts and minds of the locals which is vital in fighting asymmetrical warfare; and the mandate should not be changed frequently. The findings generated a body of knowledge that informs designing of peace support operation practices, processes and strategies for ensuring durable and sustainable peace in Somalia and elsewhere.
\end{abstract}

\section{Subject Areas}

Politics

\section{Keywords}

Peace Building, AMISOM, Peace Support Operations, Al Shabaab 


\section{Introduction}

The unending violence in Somalia saw the deployment of AMISOM in the failed state. AU through the support office of UN has been able to launch peace support operations. Somalia remains unstable since the fall of national government in the early 1990s. Previous peace support operations failed to meet their mandates. AMISOM has been in Somalia since 2007. They have been supporting the weak Federal Government of Somalia in stabilization plan. Violent conflicts continue to unfold fresh gridlocks for peace support operations not limited to; unpredictable cost of wars; uncertainty in ending protracted intrastate conflicts in the post-cold war periods and the ever changing face of asymmetrical warfare. The urgency of a solutions based approach to such impasses occasioned in peace support operations is real, especially at a time when UN, regional security mechanisms and the international community are grappling with the actualities of human cost and material support in peace building schedules. Given that Somalia's unending violent conflict threatens regional peace and stability, and that previous interventions for Somali wars failed to yield durable peace, the question of whether or not current mounted peace support operations will live up to expected scorecard performances to deliver sustainable peace is imperative.

Peace support operations (PSOs) have become the most important means for the international community to intervene in conflict-ridden areas. Their primary aim is creating political change in these areas by reducing the level of violence and addressing the deep roots of structural violence to end the conflict [1]. Since the end of the cold war, most conflicts around the world have been intrastate ones that occur in weakened and failed states where political systems no longer function by exercising effective sovereignty and can no longer ensure a monopoly over the organized use of force [2]. These are often states where local politics takes place under the patronage or backing of different militias serving a diversity of interests including economic ones [3]. In such situations conflict often escalates and local violence travels across state borders to endanger regional or even global stability and security. The Somalia insecurity is currently threatening region's stability as it presents good platform for training terrorists. In such contexts, change implies transforming local social and political orders.

Local groups in such conflict arenas become targets for the military because they provide aid and pools for recruiting enemy combatants. In such situations peaceful activities exist side by side with terror attacks and humanitarian operations take place in the shadow of armed struggle. Moreover, fighting is not restricted to relatively isolated sectors but may flare up anywhere and anytime and as a consequence conflicts "have neither an identifiable beginning nor a clearly definable end". War among the people is nonlinear, is complex, is over hearts and minds, and is about creating conditions for political solutions [4]. Wars among the people may take different forms as in Iraq, Afghanistan, Somalia, Kosovo, and Palestine, but all of these struggles have significant commonalities such as malleable objectives, unclear boundaries among the tactical, strategic, 
political, and military levels, an emphasis on force protection (and not only mission accomplishment), and asymmetrical relations between nonstate and state actors.

\subsection{Nature of Operations}

The nature of operations should support the peace building strategies. Some practices would slow down the whole process. In the conduct of their operations, AMISOM has shown glaring gaps. The structures that support such peace building strategies are neither weak nor have not been put into place. The military component of the mechanism needs to secure the country against the militants' attacks. On the other hand, the armed groups have vowed to keep on with belligerence until AMISOM troops leave Somalia.

The nature of operations can be scrutinized in terms of military formations, tacticizations of the operations, cultural intelligence, counter offensive and defensive measures, strategic attack, weaknesses and the strengths of the militant group, weaknesses of military contingents and tactical disposition. These factors affect the peace building process. The military outfit has to readjust its strategies towards the achievement of durable peace.

\subsection{Military Formations}

A number of international and Somali scholars have examined the peace and conflict in Somalia [5]. The dominant position among most international scholars is that since Somalia is a failed state, the best solution is to reconstruct Somalia into a democratic and developmental state. These called for peace support operations to bring order and law into the militia run state. PSOs are carried by multidimensional forces. The military component exercises the use of coercive force to ensure cessation of hostilities. "It is embarrassing if AMISOM troops are not able to effectively fight the militant groups. It makes the locals lose credibility on AMISOM for protection. They mount roadblocks and collect taxes from the locals by force", says informant. As envisaged in the securitization theory, the actor who is supposed to provide security services should be capable of providing the services. Troops should be well equipped for the mission. Contact dilemma espouses the need for building a strong force which does not run at the "crack and thumb" of an enemy fire.

Despite variations among them, military cultures around the world (and especially in alliances like NATO) have strong commonalities facilitating their working together [6]. With less developed armies, such commonalities are not appropriately harnessed. This is occasioned by different doctrines and trainings. They also have different equipment. These commonalities centre on such characteristics as a focus on collective violence necessitating close coordination, strong hierarchies, clear chains of command, readiness of soldiers to put their lives and bodies at risk, and the importance of morale and cohesion. As a consequence, a number of administrative measures have been put into place to facilitate interorganizational 
collaboration and assistance. The mechanisms to ensure such coordination are still lacking. One respondent observed that:

AMISOM has not developed mechanisms to ensure that activities are mutually coordinated with the components; military; police; and civilian. Lack of contact points makes each component work on its own. Unlike cog in the machine scenario, the activities ought to be synchronized. Each troop contributing country is working independently of each other. The force commander has little or no control at all of the contingents since they still get orders from their home country. This gap is easily exploited by $\mathrm{Al}$ shabaab. It explains why during attack on a base, the rescue team was not sent to the soldiers under distress until the fourth day when nearly all of them had perished.

\subsection{Tacticization of Operations}

In all of the PSOs, the assumption is that the military continues to be the central actor even beyond the stage of pacification and stabilization [7]. This assumption is often reinforced by the idea that the armed forces is the only organization capable of carrying out such missions given that as an organization it is large, disciplined, and used to working under trying circumstances and wields resources. But the unintended consequence of this situation in which the military is the central actor tasked with implementing most of the goals of PSOs is the continued centrality of military ways of thinking and operations. An informant advised, "military planners should be monitored by the civilians. Mission gets challenged by high turnover of civilian staff. The civilian component should carry out its role as required. Quick impact alternatives deployed by the military might not work efficiently especially if one is battling an insurgent group".

The process of tacticization is further related to a structural differentiation within military organizations between the planning and implementing levels. The planning sections one can often find an internalization of the new modes of knowledge necessitated by PSOs and sometimes close coordination with civilians, the problem is operationalizing this knowledge. Put somewhat simply, but not simplistically, while the staff and planning elements are often very aware of the overall strategy of an operation, the actions of the implementing units are often accompanied by overtacticization. The reason for this process is that the translation between higher and lower levels inevitably involves simplification (e.g., basing action on simple causal assumptions) so that missions goals can be translated into action. A former Chief-of-Staff of the Israel Defense Forces once explained this process as a move down nine levels of hierarchy between the head of the military and the strategic corporal [8]. This situation creates huge difficulties in operationalizing the abstract insights and understanding of the strategic level down to the level of the combat units. To be sure, civilian organizations need to devise tactics as well if PSOs are to succeed(Informant).

Moreover, as one proceeds down the chain of command, the military ethos of the combat arms becomes stronger and therefore the resistance to the civilian sides of PSOs becomes stronger. For example, when missions are seen as diverging 
from combat they are often labeled negatively, as temporary tasks before returning to the "real" thing or as peripheral to the serious side of soldiering.

\subsection{Cultural Intelligence}

Cultural intelligence is a concept that cannot be ignored in contemporary military operations. The move toward cultural intelligence-centred on knowledge of the culture of adversaries-is plainly not an organizational fad for many armed forces have adopted concrete measures to institute this kind of knowledge. For instance, aspects of cultural knowledge are now integrated into military education, intelligence systems, and new organizational entities, known also as "human terrain", [9] and they belong to what Hoogenboom calls "grey intelligence", or the increasing mix of intelligence gathering operations involving public and private entities and formal and informal initiatives. In one example, the Pentagon has initiated a program through which social scientists are embedded with brigades in Iraq and Afghanistan to serve as cultural advisors to their commanders.

AMISOM should begin to carry out simulations and workshops aimed at exposing forces to the importance of religious and cultural issues in missions abroad. This can be done during predeployment training. In examining the importance of cultural intelligence for PSOs, there is contention that the production of such knowledge is primarily a response to the militarization of intelligence in such missions. The difference between two types of cultural intelligence, is that the first is environmental and necessary to develop cognitive and behavioral abilities to adapt to the context of a mission, while the second is operational in nature and needed for understanding the enemy and the theatre of conflict. The first type of cultural intelligence is the necessary qualification for the second that plays an important role in developing strategies and allocating resources within PSOs.

Exploitation of cultural intelligence plays a key role especially in information gathering. To date, most of the locals view AMISOM troops as invaders. This is further underscored by the theory of securitization that the audience should support the war efforts. This is purely the AMISOM's duty to seek acceptance from the locals. That kind of mind set could have been toned down by understanding the importance of cultural intelligence. Soldiers should reinforce what is acceptable by embracing cultural practices of the Somalis. That should be balanced not forgetting their role as peace enforcers.

\subsection{Counter Offensive and Defensive Measures}

AMISOM continues to conduct counter insurgency operations against the armed militant groups. The counter offensive operations have seen many towns and centres liberated. In August 2011 African troops together with TFG forces managed to push Al-Shabab out of the Somali Capital; Mogadishu. The success is also attributed to more troop contributions from member states (Kenya and Djibouti); greater coordination between AMISOM and TFG forces; and reported 
training of Somali intelligence operatives by the Central Intelligence Agency.

AMISOM should intensify more offensive actions. Gains made in the past are being eroded by the successful attacks that $\mathrm{Al}$ shabaab has conducted on the bases. One informant decried that:

Troops seem to be ceding more ground to $\mathrm{Al}$ shabaab due to many reasons. The troops lack necessary equipment to conduct counter insurgency operations-night operations are nearly impossible due to lack of night vision devices. Militants normally move at night under the cover of darkness, so ambushes should be laid at night to catch them of guard. Air strikes are limited or not at all, the absence of air assets gives them insurgents a lot of space for freedom of action. We hardly conduct offensive patrols. The defenses must be offensive in nature. Fighting patrols should be sent out and due to lack of intelligence and drones for aerial surveillances such operations is hardly feasible. Instead, Al shabaab attacks us at will, meaning that they bring battle to our defences. We fight at their own convenience and a place of their own choosing, which is a real tactical blunder on the side of the AMISOM troops. Troops are should be well equipped and at least the mission should have some few attack helicopters so that we can degrade the militant's capability.

During the mid 2012 AMISOM made a lot of gains [10]. The involvement of the Kenyan Defense Forces (KDF), which is well equipped and includes a large Navy and Airforce, has greatly contributed to the achievements against Al-Shabaab. In addition, Ethiopia has redeployed troops into Somalia, capturing Beledwyne and has also moved into the central regions of Hiraan and Galgadud and further still into the Shabelle River Valley. The KDF has liberated Gedo, Juba, Kismayo, while AMISOM forces have pushed Al-Shabaab from the capital, Mogadishu. Coordinated efforts of Kenya, AMISOM, Ethiopia and Somalia have had limited gains in ousting insurgents from most parts of Somalia [11]. Theory of contact-dilemma pushes for a well defended localities with a defensive position which is quite offensive in nature. Troops who are well rehearsed and conversant with battle drills. They must understand the groupings of weapons to achieve the desired firepower.

The Burundian and Ugandan armies have significant experience in insurgency warfare due to experience gained in the protracted civil wars they experienced in their countries. AMISOM ought to exploit that experience. They have demonstrated more resilience to the asymmetric warfare. This can prove to be invaluable in defeating and pushing the Al-shaabab out of Mogadishu and completely eradicating the militant's menace.

\subsection{Strategic Attack}

In the war against insurgency, planners keep strategic attacks key to the decisive engagements with the enemy. Application of the strategy weakens militants since it exploits their weak points. Strategic attack is offensive action specifically selected to achieve national strategic objectives. These attacks seek to weaken the adversary's ability or will to engage in conflict, and may achieve strategic objec- 
tives without necessarily having to achieve operational objectives as a precondition. Strategic attack involves the systematic application of force against enemy systems and their centers of gravity, thereby producing the greatest effect for the least cost in blood and treasure. Vital systems to be affected may include leadership, critical processes, popular will and perception, and fielded forces [12]. Strategic attack provides an effective capability that may drive an early end to conflict or achieve objectives more directly or efficiently than other applications of military power. Air, space, and cyberspace power has inherent, unique advantages in conducting strategic attack, with the distinct aim is producing effects well beyond the immediate tactical and operational effort expended and of directly contributing to achieving strategic, war-winning effects and objectives. Such offensives target activities or places where these armed groups least expect. In the fight against $\mathrm{Al}$ shabaab and other armed groups in Somalia, AMISOM needs to employ strategic attacks in degrading the capability of these militants. A clan elder said, "these militants still control and govern the rural areas in Somalia. They carry out their businesses such as tax collection without any fear. They have adequate ordinances to plant IED attacks on the AMISOM troops".

AMISOM should find out the sourcing of funding of Al shabaab; their means of transport when smuggling the contraband goods and equipment and their training grounds. Attacking and completely blocking their source of funding will paralyse their operations. As observed by the researcher, one needs money to feed, clothe and arm the soldiers in order for them to fight effectively. The rag tag soldiers too need these basics and most importantly salaries to keep them motivated. Most of the ports have been taken by the AMISOM forces; however, the armed groups still collect taxes from charcoal and contraband goods on transit to different parts of Somalia. An informant recounted that Al shabaab roams villages terrorizing locals. At times, they demand for food and do forceful tax collection. They threat with physical harm if one refuses to comply with their demands.

Physical destruction of the fire power of $\mathrm{Al}$ shabaab remains key in the defeat of these armed groups. Foreign fighters have infiltrated the ranks of Al shabaab. An informant observed that they have perfected the employment of IED attacks on the AMISOM troops. Through expansive intelligence, AMISOM needs to find these individual who have the expertise in IED making. Their mortar attacks on major towns like Baidoa and Mogadishu indicates that they have various experts in these fields. "In the month of August, there were two mortar attacks which killed civilians and injuring scores of people", noted a clan elder. These experts need to be single out and arrested or put under custody b the AMISOM forces. These people act as force multipliers to the militant group. Eliminating these experts will cripple the operations of $\mathrm{Al}$ shabaab.

Radicalization drives Somali youths into joining the terror group. A clan elder shared that youths disappear from homes only to join Al shabaab. Once they join the outfit, they become radicalized. Deradicalizing them becomes hard without the help of experts. Radicalizing the youths remains a major way of retaining the 
youths to fight for the group. AMISOM should build an institution which is aimed at mentoring the youths and deradicalizing them. These will curb the number of the youths joining $\mathrm{Al}$ shabaab.

Strategic attack requires understanding of human terrain. Developed nations have introduced training of human terrain systems in order to provide a deep understanding of the environment in which they operate. The concept of "human terrain" has been defined in military documents pertaining to human terrain system as the human population in the operational environment... as defined and characterized by sociocultural, anthropologic and ethnographic data and other non-geographical information [13]. In the most immediate sense, human terrain system was developed as a response to concerns about mismanagement of US military operations in Iraq and Afghanistan, and, in particular, to the negative effects of recognized "deficiencies" in US military "cultural understanding" of these countries [14]. AMISOM should be able to comprehend the environment in which they operate. The mission fails to appreciate the demographic perspectives as well as cultural practices of the Somalis. This too will help in easing acceptance of the troops amongst the host. Failure to understand this key concept has created a rift between the troops and locals. On clan elder mentioned that some Somali view the troops as invaders. AMISOM has not worked hard towards winning the acceptance of the locals. This can be seen by Al shabaab planting IED in towns and at the "doorstep" of the AMISOM bases targeting the troops. Locals fail to inform troops about these activities due to lack of acceptance.

Human terrain system remains effective cultural tool that can help the leadership of the troops both at the tactical, operational and at strategic levels. It reinforces the winning of loyalty of the locals. This battle for control of and support from a contested population can only be won if AMISOM understands the Somali people, whose cooperation, trust and support should be secured. Armed with this understanding, commanders at level can navigate the human terrain successfully. Without it, they will continue to be confused by the complexities of their culture, faith and society; oblivious to their desires, grievances and opinions; distracted by the lies and distortions of the enemies; and blind to opportunities to enhance our reputation. In building of an institution to rehabilitate the youths and provide them with meaningful skills for creating jobs, some human terrain teams should be established by the mission. The teams should be embedded with the contingents. It will facilitate the appreciation of importance of human population in the operational environment. It tells them what Somalis' expect from their Federal Government and what they need to survive and prosper. It informs the troops how to avoid cultural missteps and explains the narratives that they must understand and utilize in order to communicate effectively with the population. It identifies $\mathrm{Al}$ shabaab behaviors and excesses that the population rejects and can be exploited, while providing Somali perspectives on how to exert pressure on and defeat these armed groups. In winning the insurgency warfare, human terrain cannot be brushed aside. 


\subsection{Weaknesses and Strengths of the Militant Group}

Counterinsurgency requires a deep understanding of the organization of the armed groups. Knowing strengths and the weaknesses helps in understanding of the enemy. The commanders should carry out threat analysis and threat integration with regards to the enemy posture. This forms the basis in the fight against Al shabaab.

Threat evaluation involves knowing the enemy strength, their dispositions, their capabilities and morale. This helps in identifying the gaps that can be exploited to defeat their fighting power. One respondent regretted that "from the engagements we have had with Al shabaab, at times it seems that even the commanders are not sure of the kind of the enemy that is being fought, they type of equipment they have and even their deployment'. Threat evaluation and analysis helps the soldiers in understanding the enemy thus they get prepared both physically and psychologically. The commanders are therefore able to adjust the quantum of firepower needed to defeat the armed group. Fighting insurgent groups who are motivated with high levels of morale can be essentially fatal. Their high levels of morale need to be vanquished before actual destruction.

Threat integration gives the commanders planning guidelines after evaluating the enemy. The commander needs to adopt the best course of action to neutralize and defeat the belligerents. The firepower to deliver to threaten the enemy should be adjusted based on the capability of the enemy. An informant observed, "AMISOM has not efficiently analysed Al shabaab. This has occasioned tactical blunders within the AMISOM bases. Some of our bases were overrun but had we analysed the enemy well, we would have contained the attack".

One must know the enemy which he is fighting. Discerning the weaknesses and strengths of $\mathrm{Al}$ shabaab and other Islamic militants forms a crucial lead in the degradation of their capabilities. Commanders at all levels should utilize the weaknesses and strengths posed by the enemy for the success of their operations.

\subsection{Tactical Disposition}

The battle posture adopted by the troops determines the successes of the operations. The deployment of troops with regards to movements of the enemy influences the fluidity and the momentum of the activities intended to defeat the armed groups. The stationing of the outpost should deny Al shabaab the freedom of movement. Leaving them with large unmanned spaces allows them to perform any maneuvers they so wish.

"We have some bases which are not tactically located making it hard to defend such outposts. Some contingents insist on such posts because it is informed by the troop contributing country's strategic interests", observes an informant. Location of defended outposts should be informed by tactical considerations. The deployments are supposed to help stabilization processes of Somalia. There are still strategic towns which are yet to be captured. Jilib, El ade and Jamaame which form part of Jubaland Corridor. This space offers safe havens for the Islamic militant group. These towns need to be captured by the AMISOM. 
Tactical disposition should also take terrain analysis and weather into perspective. Defended localities are situated on grounds which offer tactical advantage to the troop. These areas should have good fields of view and should be dominated by fire. Place which are affected by floods during rainy seasons should be well drained to avoid outbreak of communicable diseases at the onset of rains. $A$ respondent explained that some of the defended localities are not tactically cited. These makes defence quite hard when the enemy launches an offensive.

With the Mandate due to expire yet AMISOM has a lot more to be done in order to stabilize the country. The issues mentioned in this chapter need to be readjusted to make the nature of AMISOM relatively more efficient.

\section{Conclusion}

Nature of AMISOM plays a vital role in relation to peace strategies in Somalia. How the mission is configured to carry out its mission affects its adeptness. Military formations have to allow competent deployment of military resources available. All TCCs should work towards a unified command. Lack of synchronized systems hinders productivity of the troops. Troops pending mission deployment should undergo predeployment training based on a particular doctrine. Unity of effort is reinforced by coordination of the activities. AMISOM has not developed liaison mechanisms and contact points between itself and other actors in the theatre. They should synchronize their actions in combined efforts with other international bodies working towards stabilization of Somalia.

\section{Recommendations}

Based on examination of the nature of AMISOM in relation to peace building strategies in Somalia, the study recommends that AMISOM mandate should not be changed frequently. The mandate should run for at least two years before its renewal and based on the progress. Additional troops should be sought out. The current strength is not enough to secure the country against the militants. Forces which lack impartiality required for participation in peace support operations should be removed. If possible, forces which share common borders with Somalia should not continue to serve as part of the AMISOM mission. Those forces must be replaced by contingents from other countries, which do not have territorial ambitions, or historical enmities that will affect the mission. Otherwise, the locals will continue to view them as occupation forces.

Winning the hearts and minds of the locals is a key confidence building tool. Provision of services such clean drinking water, medical services and recreational facilities remain critical in attaining the mission of AMISOM. Building, gaining and maintaining public confidence is vital in defeating $\mathrm{Al}$ shabaab. Fighting irregular warfare needs public support. These efforts can be complemented through: AMISOM taking disciplinary measures against any personnel accused of any misconduct; and conducting civil-military relations frequently.

The areas which remain strategic to Al shabaab, should be pacified. The Juba 
Corridor which runs from Jilib town to Gedo regions should be captured from the militant group. They get a lot of freedom of action in the region. The can freely perform both administrative and tactical movements. AMISOM should harness its military superiority to degrade the capabilities of the armed militant groups. Through strategic attack, AMISOM should ensure that the militants' bases are unoperational.

\section{References}

[1] Onditi, F.O. (2015) Civil-Military Relations Influencing Visibility of Multi-Dimensional Peace Support Capabilities within the Eastern and Western African Standby Forces, 2004-2014. PhD. Thesis in Peace and Conflict Studies, Masinde Muliro University of Science and Technology, Kakamega.

[2] Reno, W. (2011) Warfare in Independent Africa. Cambridge University Press, New York. https://doi.org/10.1017/CBO9780511993428

[3] Kaldor, M. (2001) New and Old Wars: Organized Violence in a Globalized Era. Polity, London.

[4] Munkler, H. (2005) The New Wars. Polity, London.

[5] Rutherford, K. (2008) Humanitarianism under Fire: The US and UN Intervention in Somalia. Kumarian Press, West Hartford.

[6] Tresch, T. (2007) Multicultural Challenges for Armed Forces in Theatre. Military Power Revue, 35, 23-30.

[7] Kobi, M. and Eyal, B. (2011) Contemporary Peace Support Operations: The Primacy of the Military and Internal Contradictions. Armed Forces \& Society, 37, 657-679. https://doi.org/10.1177/0095327X10390467

[8] Michael, K. (2007) The Israel Defense Forces as an Epistemic Authority: An Intellectual Challenge in the Reality of the Israeli-Palestinian Conflict. Journal of Strategic Studies, 30, 421-446. https://doi.org/10.1080/01402390701343417

[9] Hoogenboom, B. (2006) Grey Intelligence. Criminal Law and Social Change, 45, 373-381. https://doi.org/10.1007/s10611-006-9051-3

[10] Meleagrou, A. and Hussein, S. (2012) Factors Responsible for Al-Shabab's Losses in Somalia. International Centre for the Study of Radicalisation and Political Violence (ICSR), King's College, London.

[11] Hesse, B. (2014) Two Generations, Two Interventions in One of the World's Most-Failed States: The United States, Kenya and Ethiopia in Somalia. Journal of Asian and African Studies, 1, 1-28.

[12] Hosmer, S. (2001) Operations against Enemy Leaders. Rand, Santa Monica.

[13] Kipp, M. and Jacob, H. (2006) The Human Terrain System: A CORDS for the 21st Century. Military Review, 86, 8-15.

[14] Maximilian, C. (2011) The Human Terrain System and Anthropology: A Review of Ongoing Public Debates. American Anthropologist, 113, 149-153.

https://doi.org/10.1111/j.1548-1433.2010.01315.x 
Submit or recommend next manuscript to OALib Journal and we will provide best service for you:

- Publication frequency: Monthly

- 9 subject areas of science, technology and medicine

- Fair and rigorous peer-review system

- Fast publication process

- Article promotion in various social networking sites (LinkedIn, Facebook, Twitter, etc.)

- Maximum dissemination of your research work

Submit Your Paper Online: Click Here to Submit

Or Contact service@oalib.com 